\title{
Violence Patterns in Peckinpah's The Wild Bunch (1969): Critical Reading
}

\author{
Baker Bani-Khair (Corresponding author) \\ Department of English Language and Literature, Hashemite University, Zarqa, Jordan \\ E-mail: bakribakr@yahoo.com \\ Nayef M. H. Alshboul \\ Yarmouk University, Jordan \\ E-mail: Nayefshboul8@gmail.com \\ Nisreen Al-Khawaldeh \\ Department of English Language and Literature- The Hashemite University, Jordan \\ E-mail: nal-khawaldeh@hu.edu.jo \\ Imad Al-Khawaldeh \\ Hashemite University, Jordan \\ Mohammad Ababneh \\ Language Center, Hashemite University, Jordan
}

Received: 27-11-2016

Published: 01-05-2017
Accepted: 19-01-2017

Advance Access Published: March 2017

doi:10.7575/aiac.ijalel.v.6n.3p.210
URL: http://dx.doi.org/10.7575/aiac.ijalel.v.6n.3p.210

\begin{abstract}
This paper focuses on the issue of violence in Sam Peckinpah's The Wild Bunch (1969) through explaining some of the cultural and historical implications of violence in the 1960s such as Vietnam War, the Mexican war and also the explosion of the feminist movement and some other important social and political upheavals that shaped the cultural context of the 1960s in America. It also sheds light on Sam Peckinpah's approach of violence screen and stylizing violence and the representations of violence as a tormenting and brutalizing reality that matches the spirit of the age in addition to the social, political, and colonial conflicts of the 1960s. Violence and the implications of violence in The Wild Bunch whether social, cultural, psychological, or humanistic have been discussed in brief in order to show the critical approach of the film as being a rich and didactic film to watch, especially in terms of its rich cultural and historical contexts.
\end{abstract}

Keywords: film theories, violence, screen, mise-en-scene, Sam Peckinpah, Feminism

\section{Introduction}

Sam Peckinpah's The Wild Bunch is one of the films that primarily deal with violence and its representation within the framework of the social, historical, and cultural aspects of the society in the 1960's in America. The representation of violence in The Wild Bunch is one of the most prevalent things that the director constantly shows to audience throughout the whole movie. In this paper, we investigate the issue of violence in its ramified patterns in the film which shows several types of violence on different levels: psychological, social, and domestic ones. We also study the connections of violence with aspects of historical and contextual situations through a critical reading of the film which can help the reader understand the intertwined relationships and roots of violence implications on the screen, especially in such an important era of the 1960s that witnessed multifarious events and upheavals of extreme significance to the whole world. Despite the fact that film was directed in 1969, it still carries some essential points that need to be studied and analyzed, particularly those which concern with violence as a realistic problem. Having seen this film more than once, we started to realize the importance of connecting the issue of stylizing violence with the 1960's cultural and historical implications that were associated with war as well as domestic violence which the whole movie revolves around. In addition to that, the violence that we see in The Wild Bunch is also associated with some cultural and social events and upheavals of the age itself such as feminism movement, colonization, war, political conflicts, and racial problems at that time. For example, the issue of war is one the main focuses that draws the attention of the audience since it relates to a broader theme which is war violence. Stephen Prince in Classical Film Violence states that "violence in The Wild Bunch reflects the savagery of the Vietnam War." (3) Societal issues and dilemmas are also represented 
such as the image of woman in America. The film reminds the viewers as an anachronism of the rise and explosion of "feminism movement" in the 1960s.

\section{Discussion and Analysis: The Image of Woman in The Wild Bunch}

Different patterns of violence can be observed in the film. One of the most prevalent and dominant issue is violence against woman which represents a historical and contextual one which took place over an extended period of time during the last century. The film shows those patriarchal patterns of woman oppression through an unconscious negative representation of behaviors and attitudes against woman. Those patterns might, of course, symbolize a realistic time period of continuous oppression and deprivation during which women had to suffer much and struggle hard to establish their identities. The viewers will easily sense the atmosphere of patriarchal domination from the first scene until the last shot in the movie. It is noticeable that the film comes represent anachronisms of a vanished westernlifestyle that heavily depended on manhood and masculinity of perhaps a previous century before the 1960s, but still those scenes can vividly echo the 1960s upheavals and chaotic events, including woman oppression. Psychologically speaking, violence against women whether physically, sexually, or morally is part of the message revealed in The Wild Bunch. The violence against women we see on screen was the representation of a severe reaction against the explosion of the feminist movement in the 1960s. Peckinpah's film the wild bunch is a clear representation of the social reactions against feminism. However, this reaction was mixed with much more savageness and ugliness which the film stresses to depict women's suffering due to their feminist views that come as social and political reactions against the mainstream thought. One of the most historical aspects that relates to violence from a feminist perspective is savageness and violence against women. Women are represented as commodities rather than being actually respected members of the society. Their roles have been diminished to a low status of savage sex that suits a savage masculine system and an oppressive patriarchal society. Bill Mesce argues in his book, Pickenpah's Women: A reappraisal of the portrayal of Women in the Period Westerns of Sam Pickenpah, argues that women in The Wild Bunch are represented as complete failure of men, and he refers to the "misogyny" in Pickenpah's The Wild Bunch, he states that, "women may be able to morally trump men but in the wild bunch, for the first time they are just as fallible. Rather than misogyny, this represents a harsh, uncomfortable, and unflattering equivalence, but it is an equivalence nonetheless" (125). Mesce gives examples on this when he says, "women are not deeply involved in the goings on of the film, which makes the wild bunch more true to its story than Pickenpah's earlier films. Yet, they serve as enormously important markers. Discussion of Pickenpah's women invariably becomes about his men, because the women stand as the gauges of the sundry failings and failures of the men.” (127)

Bill Mesce also notices that such violence against women on screen was a reaction to the actual violence against feminism in the 1960, he says "Increasing violence against women on screen was, and continues to be, viewed by a number of observers as "hysterical response to sixties and seventies feminism: the male spectator enjoys a sadistic revenge on women who refuse to slide neatly and obligingly into his patriarchally determined view of "the way things should naturally be." (153)

From this perspective, the violence that we see in The Wild Bunch is more likely to be a response to some important historical and cultural issues. Despite the fact that we cannot expect The Wild Bunch to give an exact image of the society since it can be seen as a misrepresentation of culture and society, but we can approach the film from a cultural and a historical perspective which can broaden our own understanding of the historical and cultural implications of violence and the causes to screen violence and stylizing it in a way that appeals to the modern viewers on TV in the 1960s.

\section{Method and Approach (Film Theories): Violence and the Mise-en-scene}

Film criticism gives insight into the depth of the visuals and mechanics of the film extensively. There are different approaches which tackle specific goals and angels in the film. For example, Auteur theory specifically focuses on the connections between the film and the director's vision and goal. The formal approach, like formalism in criticism, highlights the form and the style of the film. The psychoanalytic approach focuses on the psychological aspects and emotions that the characters show on the screen. However, in this paper, we prefer to imply different approaches as to investigate in depth all aspects of Pickenpah's film. We notice, Peckinpah's approach of screening violence in The Wild Bunch is extremely intense and confusing due to the anxiety it creates for the audience. We definitely understand how difficult it is to explain Peckinpah's approach in creating this anxiety, but Peckinpah's The Wild Bunch is probably a reaction or a criticism to societal and global violence at that time. Although violence that we see in Peckinpah's The Wild Bunch might seem realistic in the sense that it is connected with war and domestic violence, but one can also doubt how violence seems unbelievably normal in the real sense as one watch The Wild Bunch. It causes unrestful reactions from the viewers, but it also has this desensitized response due to exaggerated blood screening on the screen. The point that is crucial to discuss is that violence in The Wild Bunch seems more like a criticism of the social and political system rather than a real and trustable representation of reality. In this case, and from an auteur theory perspective, Peckinpah wants violence to appear as an abominable experience that triggers sympathy, pity, and criticism from the viewers. Despite the fact that violence in the film seems to appear natural in the sense of desensitization that it creates due to carelessness that the characters (actors) show when they exaggerate in evil acts, which in fact, works as a terrifying and tormenting experience for the audience in the sense that suffering, pain, killing, shooting, and bloodshed all seem natural, acceptable and normal act.

We cannot neglect the fact that Peckinpah structures violence not just to appear as a representation of the dark side of the human nature, but also as a sign of backwardness, savagery, inhumanity, corruption, and brutality. The shocking 
thing in this film is that violence seems as a natural habit which is viewed as part of the lifestyle of the society rather than being a deviation. Simply the film leaves no outlet for any shadows of hope. We also cannot find a single character that can basically represent goodness. The film puts us in a vicious circle in which we can only see violence. Thus, the film is suffocating due to its limited scope that the director designs to position the viewers in. It is not only the bunch or just the group of outlaws that we can think of as being "wild" and "savage", but every one that we see on the screen appears to us as such including children, women, and elderly who lost innocence. We do not see a single case where we can pick an example to identify as being a representation of the norm (goodness). The only thing that we see is the deviation.

Part of the historical significance that the film provides us with is the richness of the cultural and social contexts which are direct references to both Western and Mexican cultures. The film could be seen as a keen observation of the society from Peckinpah's personal view, which constantly appears as a dominant feature in the film. Prince refers to this idea in his Sam Pecknpah's The Wild Bunch, when he talks about Peckinpah and violence screen. He explains that Peckinpah contributed to film development and violence screen through his own keen observations and responses of the culture and the society, and also through his criticism of screen violence in previous films adding new sophistications and techniques to film production and violence screen, as we may note in this quotation when Peckinpah describes The Wild Bunch, he says, "The Wild Bunch was my way of reacting against all the films in which violence seemed facile, factitious, and unreal. I was always fascinated how one died easily in the movies...people die with suffering and violence provokes no pain." (26)

Prince also notes that Peckinpah was doing novel things to updating and stylizing violence screen making violence appears as a terrifying and stimulating powerful experience which is totally the opposite from the traditional scenes of violence that appeared on the screen before Peckinpah's new montage editing, as Prince states, "Pickenpah's screen violence hurts and it is situated within a context of loss and sadness that works against the exciting stylistics of the montage editing" (26)

The film tends to create a realistic as well as an imaginative manipulation of reality which we continually criticize throughout the whole movie. Part of this was the repeated use of quick and slow motion that is associated with the scenes of killing and shooting. In fact, this was part of the artificial montage editing that were brand new at that time that the director wants to refer his audience to, but also those new techniques emphasize the point where Peckinpah projects the context of violence from a cultural and social perspective. The issue of violence is depicted as one of the ugliest realities that one can ever find in films, especially if we consider the social themes along with the cultural ones. The Wild Bunch's message is to show the viewers how violence can be painful and destructive on both the society and the individual. As Prince in Screening Violence explains that Peckinpah was interested in showing how brutalizing and horrible violence is in reality, therefore, Peckinpah broke the old conventions of violence screen to meet the didactic purpose of his film. Prince explains that Peckinpah wants to show the horror of violence in the real sense, he clarifies that, and "by breaking the established representational conventions, peckinpah hoped to convey the horror of violence to viewers he believed had been rendered complacent by decades of painless, bloodless movie killings. In late $960 \mathrm{~s}$ America, the traumatic impact of real social violence was misaligned with the tradition of sanitized movie violence." (170)

\section{Violence as a Human Tragedy in The Wild Bunch: The Representations of Violence}

The Wild Bunch covers some of the crucial universal dimensions that Peckinpah associates with violence in his film. From our point of views, the universality we see here makes The Wild Bunch an attracting film to watch simply because it doesn't only deal with domestic violence, but it also tackles with a human issue through depicting violence as a human tragedy that leads to destruction of both the society and the individual. This is actually very noticeable in the closing scene in the film when we see all involved in bloodshed and killing. This raises a point to the viewers to ask about the outcome of violence because we didn't see a winner but more bloodshed and killing. In fact, despite the large emphasis that Peckinpah placed on the issue of violence from a cultural and a social perspective within the framework of military colonization and war, he also makes violence appear as an intrinsic drive that has roots in the human nature itself. Pekinpah depicts violence as an inner conflict and an instinctual drive that comes out from within not just from outside.

From my point of view, the film is an excellent example of how evil and violence can be approached as we move from the external to the internal. Interestingly enough, evil is represented as something desirable and wanted in the sense that it is connected with heroism, manhood, pride, and authority. Violence is also associated with sexism and race depicting women's suffering because of the savage Patriarchal domination that we see in the movie. The violence we see against the society is correlated with the masculine savageness against women, especially regarding sexuality. One can feel the filthiness and the savageness that men enjoy practicing when come to criticize the sexual relationships presented in The Wild Bunch. This is what makes the film a clever and sharp criticism of human relationships not just within the circle of violence but also within the human relations that are based on pure materialism, instincts, desires and lust. From my point of view, the director's focus on showing the materialistic aspect through uglifying the picture of human relations makes desires and instincts appear as the most disgusting things. Weddle refers to eroticism and violence in The Wild Bunch in his book entitled, If They Move-- Kill 'Em!: the Life and times of Sam Peckinpah, when he says, "eroticism and horror of violence and man's fascination with it had been just one theme among many in the epic tragedy of the wild bunch, but in siege it would become the focal. To engage his audience on an emotional level, to force it to confront its own conflicted feelings about violence, Pickenpah would have to reach down into his own guts and yank up a fistful of 
entrails". (396) From my point of view, despite the universality that we see in the film, still the film creates anxiety on a personal level in terms of its content and style which are different from the movies that we see in the period. First, it is difficult to identify ourselves with the hero in the movie because it is all evil, and also it is difficult to identify Peckinpah's scheme of violence in The Wild Bunch both as a social dilemma and a human issue, but definitely Pickenpah depicts a human issue and the destructiveness of war and violence on both the society itself and the human relations. This is why the film seems rich with the variations of different styles and techniques that Peckinpah uses to draw the attention of the viewers.

For a superficial reading of the film, one might think that the movie is more entertaining than being didactic but for a deeper reading of the movie, one can discover the deep implications of violence within the culture and history of the 1960s. Seydor Paul in his Pickenpah The Western Film: A Reconsideration referred to this theme when he explains that The Wild Bunch has been criticized for the lack of ideas. He says, "The Wild Bunch has been criticized for its lack of ideas, but that tells us less about the intellectual shortcomings of the film or the film makers than about the inability of most reviewers to comprehend how ideas really enter and operate in works of art. One reviewer claimed that for all the beauty of craft and image never has so much virtuosity been made to serve so few ideas "the moral idiocy of the wild bunch (it is alright to kill if you stay loyal to your bodies) was fairly obvious"." (173).

Despite the fact that The Wild Bunch can be seen as a medium in which we see, analyze, and criticize a community where violence and evil prevail as norms, yet the film leaves a space for the viewers to think about the roots of violence in the society and the epiphanies that the violence scenes trigger, especially toward the end of the movie and that is, actually, part of the new devices and techniques that the director uses in directing this film. Seydor notes this idea when he says, "of all Pickenpah's formal devices and techniques the epiphanies are most to the point here for it is in them that he dissolves the boundaries between foreground and background and allows irony to flow momentarily into myths and vice versa" (233).

The shocking experience in the film is the absence of goodness and the loss of innocence which aggravates the context of violence and savageness in The Wild Bunch. No one seems afraid of killing and violence, and nobody cares to stop it. We see little emotions towards it. Evil prevails and dominates the whole movie without any shadows of hope for goodness to take place. The loss of innocence seems also apparent in children's behaviors which represent the negative impacts of violence on them. As we might notice, children seem addicted to violence and also love and enjoy watching violence. In this way, goodness is brutally killed within them by evil. The complicated thing here is when we watch children's behaviors as violence appears more like an interesting game and that bloodshed is no more terrifying at all. Peckinpah aimed to bring the nastiness and painfulness of violence onto the American screen in a way that would align film with the social realities of the traumatic violence sweeping America that reminisce the Vietnamese War, urban riots, and political assassinations. Peckinpah shared his nation's grieving, shocked response to these events, and he thus insisted that, "the violence in the wild bunch carries the disturbing force of human pain and anguish" (26)

\section{Conclusion}

The paper studied the multifarious aspects of violence from several patterns and perspectives. Violence as we found out in the film represents historical, contextual, social, and psychological dimensions which all convey a realistic dilemma during that era. Violence against women and children remains the ugliest form which the film tries to highlight. Children and women as the film shows are the most vulnerable victims in a society where violence spread and chaos takes place. One of the best examples on violence is the opening scene of the movie in which we see little innocent children torturing a scorpion to death. This scene actually matches the theme of violence and the carelessness about that violence especially when we move forward a little bit in the movie and we see little children seem to love and enjoy both watching and doing violence. This theme actually correlates with the sense of the age where a lot of bloodshed and killing took place and also correlates with the theme of war, especially regarding the Mexican war and the Vietnam War where a lot of people were killed. However, the movie appeared as a sharp criticism of violence and domestic violence and crimes, and what also seem more painful is the careless and indifferent attitudes that people show towards violence which makes the movie appears all terrifying. Interestingly enough, the shallow emotions that people show towards humanity instigate deep psychological responses from the viewers. While Pickenpah's approach to screen violence seems much more focused on human suffering and the pain that violence causes to people on both the social and individual level, but still his approach mixes both the dynamicity of his criticism against a violent and savage social environment as well as the appealing sense of humor which is part of his criticism anyhow.

The superficial role that women play in the movie poses a good argument about the social status that women played in the 1960s when women were living in a male dominated society. However, women here are represented as part of a backward and uncivilized society. What is also shocking in the movie is that everyone seems pleased with the other's savageness, and women here appear just satisfied with their marginalized roles and their low status as such and they seem to accept because they didn't dare to change or revolt against such patriarchal domination. What is also shocking here is the representation of sex as being an instinctual desire that goes in line with the uncivilized attitudes and social practices of the society. Historically speaking, back in the 1960s women were struggling hard to establish a better self identity and claim equity with men. The film stands to provide a substantial idea of the soul of the age, especially about feminism movement and the reactions to that movement.

Finally, The Wild Bunch is a didactic film to watch and the violence that we see was a clear representation of actual violence on different levels at that period. We definitely see the dimensions of violence screen in The Wild Bunch from political, historical, cultural and psychological aspects. 
References

Fulwood, N. (2002). The Films of Sam Peckinpah. London: Batsford.

Prince, S. (2000). Screening Violence. New Brunswick, NJ: Rutgers UP.

Prince, S. (2003) Classical Film Violence: Designing and Regulating Brutality in Hollywood Cinema, 1930-1968. New Brunswick, NJ: Rutgers UP.

Prince, S. (1999). Sam Peckinpah's The Wild Bunch. Cambridge, UK: Cambridge UP.

Slocum, D. J. (2005) "Cinema and the Civilizing Process: Rethinking Violence in the." Cinema Journal 44.3 (2005): 35-63. Project MUSE. Web. 24 Feb. 2016. <http://http://muse.jhu.edu/journals/cinema_journal/v044/44.3slocum.pdf>.

Weddle, D. (1994). If They Move-- Kill 'Em!: the Life and times of Sam Peckinpah. New York: Grove.

Wetta, F. J., and Martin, A. N. (2003). "Now a Major Motion Picture": War Films and Hollywood's New." The Journal of Military History 67.3. Rpt. in 3rd ed. Vol. 67. Society for Military History. 861-82. Project MUSE. Web. 25 Sep 2016. 